J. Raptor Res. 48(1):78-81

(C) 2014 The Raptor Research Foundation, Inc.

\title{
Predation of Lesser Naked-backed Bats (Pteronotus davyi) by a Pair of American Kestrels (Falco sparverius) on the Island of Marie-Galante, French West Indies
}

ARNAUD LENOBLE 1

Université Bordeaux - CNRS UMR 5199 PACEA, Avenue des facultés, 33405 Talence, France

\author{
CORENTIN BOCHATON \\ Muséum National d'Histoire Naturelle - CNRS UMR 7209, Archéozoologie et Archéobotanique, 55 rue Buffon, CP 5675005 , \\ Paris, France
}

TEDDY Bos

Université Bordeaux - CNRS UMR 5199 PACEA, Avenue des facultés, 33405 Talence, France

EMMANUEL DISCAMPS

Université Bordeaux - CNRS UMR 5199 PACEA, Avenue des facultés, 33405 Talence, France

and

University of Bergen, AHKR Institute, P.O. Box 7805, N-5020 Bergen, Norway

Alain QueFFELEC

Université Bordeaux - CNRS UMR 5199 PACEA, Avenue des facultés, 33405 Talence, France

KEY WORDS: American Kestrel; Falco sparverius; lesser nakedbacked bat; Pteronotus davyi; diet; predation.

Predation of bats by raptorial birds, both diurnal and nocturnal species, has been documented in numerous cases, and can generally be classified as one of three categories (Lima and O'Keefe 2013). The first, specific specialization, refers to species with physiological and behavioral adaptations for bat consumption (Fenton and Flemming 1976), e.g., two species of bat hawks (Macheiramphus alcinus and Falco rufigularis; Black et al. 1979, Seijas 1996). The second category, individual specialization, refers to individual raptors that have specialized on bats. Examples of this type of behavior are known for Barn Owl (Tyto alba), Great Horned Owl (Bubo virginianus), and Peregrine Falcon (Falco peregrinus; Baker 1962, Looney 1972, Sick 1961, Pierson and Donahue 1983). This behavior is usually associated with hunting at large bat colonies, such as those of Brazilian free-tailed bats, as the bats leave their roost at dusk (Stager 1941, Gilette and Kimbrough 1969, Lee and Kuo 2001). The third category, opportunistic predation, corresponds to the occasional hunting of bats at colonies as they leave their roost, or the capture of isolated bats (Stoner 1939). The majority of known cases of chiropteran predation by raptors fall within this third category; examples include the Aplomado Falcon (Falco femoralis), Red-tailed Hawk (Buteo jamaicensis), and Stygian Owl (Asio stygius; Harden 1972, Hector 1985, Motta-Junior and Taddei 1992).

\footnotetext{
${ }^{1}$ Email address: a.lenoble@pacea.u-bordeauxl.fr
}

Several cases have been reported of bat predation by American Kestrels (Falco sparverius) involving wild individuals or those released from captivity (Hayse and Hayse 1963, Cruz 1976, Aguiar et al. 2012). All of these examples indicate that kestrels fall within this group of opportunistic chiropteran predators. Here we report a case of a pair of American Kestrels regularly preying upon a colony of bats in the Lesser Antilles. This example documents chiropteran predation in an area where few comparable studies have been conducted to date.

\section{STUDY AREA}

Marie-Galante $\left(15^{\circ} 55^{\prime} \mathrm{N}, 61^{\circ} 16^{\prime} \mathrm{W}\right)$ is one of several islands composing the Guadeloupe archipelago. With a mean annual rainfall of $1850 \mathrm{~mm}$, this $15-\mathrm{km}$ diameter island supports a xeric to mesic vegetation. The rainy season, from June to November, receives two-thirds of the annual precipitation with the driest period falling between the months of February and March. The island is home to eight bat species (Masson et al. 1980, Ibéné et al. 2007), a typical chiropteran assemblage for a medium-size Caribbean island (Rodriguez-Duran and Kuntz 2001) including a single carnivorous species (Noctilio leporinus), four frugivores (Artibeus jamaicensis, Brachyphylla cavernarum, Ardops nichollsi, and Monophyllus plethodon), and three species of insectivorous bats (Natalus stramineus, Molossus molossus, and Pteronotus davyi). The lesser nakedbacked bat (Pteronotus davyi) finds on Marie-Galante the most northerly extension of its range in the Lesser Antilles (Adams 1989), where a single colony roosts in the cave of Le Grand Trou à Diable (Ibéné et al. 2007). This 300-m long cave, whose 
4-m-high entrance opens in a forest located in the centre of the island, is the largest in the Lesser Antilles (Rodet 1987) and is home to five coexisting bat species (A. jamaicensis, $B$. cavernarum, $M$. plethodon, $N$. stramineus, and $P$. davyi). The lesser naked-backed bats, the first to leave the cave at dusk, likely numbers in the thousands of individuals; however, an accurate estimate is unavailable (Ibéné et al. 2007).

\section{METHODS}

We observed a pair of American Kestrels (Falco sparverius caribaearum) first in November 2011. Minutes before the bats left their roost, the kestrels settled on an electric pole near a road that the bats would cross. As the bats passed in front of them, the kestrels dove into the flock, chasing their prey. We established an observation post overlooking the roost one year later and recorded observations over a period of 16 consecutive days in November 2012. The observation post was manned by $2-5$ researchers, starting $20 \mathrm{~min}$ before sunset, in order to observe and film the scene. Observations ended a few minutes after the hawks left the site at nightfall.

We recorded the number and sex of kestrels present, their arrival and departure times, the number and time of the predation attempts, and the outcomes of predation attempts. We also noted prevailing cloud cover and weather conditions each evening. Despite the low light, we were able to determine the sex of both kestrels based on plumage and size dimorphism.

\section{Results}

Although the birds were unmarked, we believe all observations were of the same pair of kestrels, given the consistency of their hunting behavior. If not already present on the site when we arrived, the kestrels arrived a few minutes before the bats exited their roost. The two birds positioned themselves on one of the electric poles along the road and remained at their perch until the bats appeared. Several individual bats emerged from the cave during the few minutes before the formation of the flock, which consisted of a main "flight corridor" of bats and two minor corridors. As the bats exited the forest, the main flight crossed the road, passing through an exposed area where the road narrows in order to reach a hedgerow along a tractor path. The other two corridors were $20-30 \mathrm{~m}$ north and south of the main corridor. We also noted that these flight corridors differed from that observed in November 2011, when only a single flight corridor was observed.

Although kestrels occasionally attacked isolated individuals preceding the flock $(n=4)$, in most cases $(90 \%$ of attacks, $n=33$ ) the birds waited for the flock to form and then perched on the electric pole $2-3 \mathrm{~m}$ above the path of the bats. The birds subsequently attacked the flock from this position by diving into it and pursuing the targeted bat for several meters by performing a few short hooks. When unsuccessful, the bird looped back to the electric pole before making another attempt. After a bat was captured, the kestrel proceeded to a nearby perch, most often the roof of a nearby house under construction, in order to dispatch its prey. It then either moved to one of the poles along the road to eat all or part of its prey, or left the hunting scene altogether. In one case, we saw debris (a wing) fall from the pole where the falcon consumed its prey. The bones were collected, cleaned, and compared to the skeletal collection of Caribbean bats at the University of Bordeaux, confirming the prey was a lesser naked-backed bat.

We observed at least one kestrel on the site 15 of 16 evenings (frequency of occurrence $=93.8 \%$ ). Each individual bird (male and female) was present on 11 evenings on average $(69 \%)$. However, the high frequency of presence at the site was not associated with intense hunting activity: kestrels only attempted predation on the flock on six nights.

During the 16 observation days, six bats were captured during 37 attempts, resulting in a success rate of $16.2 \%$. Despite this somewhat low figure, the number of captures per bird was relatively high for each evening when hunting was documented ( 0.86 bats per kestrel and per day with attacks). Given the substantial number of days without hunting bats, the average daily rate for bat capture was low (0.19 bats per bird per day). At this rate, an annual loss by predation for the bat colony by the pair of kestrels can be estimated at 137 individuals per year.

The infrequent hunting activity, despite kestrels being present on-site, suggests one or more factors limited their hunting behavior. First, meteorological conditions typical of the end of the rainy season sometimes create unsuitable hunting conditions. For example, during the observation period, three rainy, overcast, and poorly lit evenings corresponded to days when kestrels were absent or did not hunt. The short period during which kestrels can hunt bats also likely influenced the likelihood of attacks. Bats leave the cave late in the evening, with the first Pteronotus appearing near dark; the flock usually formed 8-12 min after sunset. Consequently, any attacks on the flock of bats must occur during the very short interval from 8-13 min after sunset, which corresponds to the period during which the flock forms and the light is still sufficient to allow hunting. Although attacks did occur later in the evening, we only observed them during the few days of very clear skies when increased light enabled longer hunting episodes. This very short interval of $5 \mathrm{~min}$ therefore constrains the number of predation attempts and, consequently, the hunting success of the kestrels. This interpretation was consistent with the fact that most of the days with favorable weather on which hunting was not observed corresponded to those days when the flock formed later, some 14 min or more after sunset, as demonstrated by the correlation between the successful capture of a bat and an earlier time of flock formation (Student's $t$-test $=2.45, P$ $=0.022)$.

\section{Discussion}

Our report is the first documented predation of Pteronotus davyi by American Kestrels, and our observations are also unusual in that we report a case of regular bat predation by a pair of American Kestrels. The percentage of time kestrels were observed at the time of bat emergence 
$(93.8 \%)$ clearly distinguishes this case from the more sporadic predation by American Kestrels on the Brazilian free-tailed bats as they exit Carlsbad Cavern, New Mexico (frequency of occurrence $0.5 \%$; Baker 1962), or even the occasional presence of this species at the roost of the sooty moustached bat (Pteronotus quadridens) in Cucaracha Cave in Puerto Rico (Rodriguez-Duran and Lewis 1985). The frequency of kestrel presence at the predation site described here is among the highest frequencies of occurrence reported for diurnal raptors, comparable to those documented for the predation by Peregrine Falcon, Red-tailed Hawk, and Cooper's Hawk (Accipiter cooperii) on large colonies of Brazilian free-tailed bats in North America (Sprung 1950, Lee and Kuo 2001). The high frequency of occurrence reflects the attractiveness of the bat colony to the pair of hawks, a fact further underscored by the presence of the same species on the site a year later. The shift in the location of the flight corridor used by bats between 2011 and 2012 resulted in an increase in the number of flight paths as well as the selection of the less exposed sector of the main path. Such a change suggests an attempt to minimize the flock's exposure in response to repeated hunting, as demonstrated by Rodriguez-Duran and Lewis (1985) in Puerto Rico. It is therefore very likely that the kestrels frequent this roost regularly, if not continually, throughout the year. The estimated annual predation of 137 bats represents a loss of less than $1 \%$, which does not threaten the survival of the colony and therefore allows bats to be preyed upon by falcons over a long period.

The documented success rate of $16.2 \%$ is comparable to the $14.8 \%$ observed by Aguiar et al. (2002) in a similar situation where chiropterans were hunted by American Kestrels. However, this rate is low compared to those documented for Peregrine Falcon, Red-tailed Hawk, or diurnal raptors preying upon bats in Africa where capture rates approach or exceed 50\% (Fenton et al. 1994, Lee and Kuo 2001). This relatively low capture rate of Pteronotus davyi by kestrels did not seem to condition hunting behavior, as the success rate was high during periods of clement weather. Rather, the short window of opportunity for hunting combined with the substantial amount of time needed to consume prey are the most likely factors influencing predation insomuch as the falcons were limited to a single capture per evening.

Although the bat Pteronotus davyi probably formed only a limited part of the falcon diet, this example nonetheless showed the regular hunting of bats by American Kestrel, a somewhat unusual behavior for this species. Furthermore, we can speculate about the link between this behavior and the availability of prey in the Lesser Antilles island environment. The American Kestrel most commonly captures its prey, mainly small rodents, on the ground using a "sitand-wait" technique from a hunting perch or by hoverhunting (Smallwood and Bird 2002). However, on MarieGalante such terrestrial mammals are represented by rats (Rattus rattus) and mice (Mus musculus) introduced in historical periods (Soubeyran et al. 2011) and whose density is limited on the island. Consequently, the vertebrates that are widely available for falcon consumption are represented mainly by frogs and anoles. According to Pinchon (1976), the latter are the most common prey of kestrels in the Lesser Antilles. However, the anole species present on Marie-Galante (Anolis ferreus) is arboreal (Breuil 2002), and likely less available to kestrels. It is therefore not surprising that kestrels are frequently seen hovering above the shallow reefs to capture small reef fish at low tide (A. Lenoble unpubl. data). In an environment where prey more typical of American Kestrel are underrepresented, bat colonies represent a predictable resource. The bat predation observed at Grand Trou à Diable thus represents the exploitation of a predictable food resource in conditions where more typical prey is limited.

DEPREDACIÓN DEL MURCIÉLAGO PTERONOTUS DAVYI POR UNA PAREJA DE FALCO SPARVERIUS EN LAS ISLAS DE MARIE-GALANTE, INDIAS FRANCESAS OCCIDENTALES

RESUMEN.-Reportamos la depredación en una colonia de murciélagos de la especie Pteronotus davyi por parte de una pareja de Falco sparverius basados en observaciones en un periodo de 16 días. F. sparverius cazó murciélagos a medida que dejaban su dormidero en la tarde noche, habiendo dos factores que influenciaron la eficiencia de caza, a saber: (1) las condiciones meteorológicas y (2) el tiempo de la formación de la bandada de murciélagos. Aunque al menos un individuo de $F$. sparverius estuvo presente en 15 de las 16 tardes $(93.8 \%)$, la tasa de éxito de caza fue de $16.4 \%$ (6 murciélagos capturados en 37 intentos). Esta es la primera depredación reportada de especies de murciélagos y la primera depredación regular documentada de una colonia de murciélagos por parte de $F$. sparverius. Este comportamiento se interpreta como un ejemplo de la adaptación trófica de $F$. sparverius en ambientes de isla típicos de las Antillas Menores.

[Traducción del equipo editorial]

\section{ACKNOWLEDGMENTS}

This study was conducted as a part of the BIVAAG Program established by the CNRS with support from a European PO-FEDER grant, the Guadeloupe Regional Council and the DEAL of Guadeloupe. We thank Frederic Santos for his help with the statistics and Brad Gravina for improving the English of an earlier version of the manuscript. We'd also like to thank the three anonymous reviewers for their constructive comments, which helped improve this report.

\section{Literature Cited}

Adams, J.K. 1989. Pteronotus davyi. Mammalian Species 346:1-5.

Aguiar, L.M. DE S., A. MotTA, AND C. EsberÁrd. 2012. Falco sparverius (Aves: Falconiformes) preying upon Nyctinomops laticaudatus (Chiroptera: Molossidae). Zoologia 29:180-182. 
BAKER, J.K. 1962. The manner and efficiency of raptor depredations on bats. Condor 64:500-504.

BlaCK, H.L., G. HowARD, AND R. STJERnSTEDT. 1979. Observations on the feeding behavior of the Bat Hawk ( $M a-$ cheiromphus alcinus). Biotropica 11:18-21.

Breuil, M. 2002. Histoire naturelle des amphibiens et reptiles terrestres de l'archipel guadeloupéen. Muséum National d'Histoire Naturelle, Paris, France.

Cruz, A. 1976. Food and foraging ecology of the American Kestrel in Jamaica. Condor 78:409-412.

Fenton, M.B. And T.H. Fleming. 1976. Ecological interactions between bats and nocturnal birds. Biotropica 8:104.

- I.L. Rautenbach, S.E. Smith, C.M. Swanepoel, J. GROSELl, AND J. VAN JAARSVELD. 1994. Raptors and bats: threats and opportunities. Animal Behaviour 48:9-18.

Gilette, D.D. And J.D. Kimbrough. 1969. Chiropteran mortality. Pages 262-283 in B.H. Dallas, D.W. Slaughter, and D.W. Walton [EDS.], About bats: a Chiropteran symposium. Methodist University Press, Dallas, TX U.S.A.

HARDEN, W.D. 1972. Predation by hawks on bats at Vickery Bat Cave. Bulletin of the Oklahoma Ornothological Society 5:4-5.

Hayse, J. AND A. HAYSE. 1963. Sparrow hawk preys on Mexican free-tailed bat at Falcon Reservoir. Journal of Mammalogy 44:574.

Hector, D.P. 1985. The diet of the Aplomado Falcon (Falco femoralis) in eastern Mexico. Condor 87:336342.

Ibene, B., F. Leblanc, C. Houllemare, C. Tarlier, and C. Pentier. 2007. Contribution à l'étude des Chiroptères de la Guadeloupe. Diren, Basse-Terre, Guadeloupe.

LeE, Y.F. And Y.M. Kuo. 2001. Predation on Mexican freetailed bats by Peregrine Falcons and Red-tailed Hawks. Journal of Raptor Research 35:115-123.

LiMA, S.L. AND J.M. O'KeEFE. 2013. Do predators influence the behaviour of bats? Biological Reviews 88:626-644.

LoONEy, M.W. 1972. Predation of bats by hawks and owls. Bulletin of the Oklahoma Ornothological Society 5:1-4.

Masson, D., C. Masson, M. Breuil, And A. Breuil. 1980. Les Chauve-Souris de Guadeloupe. Société Française d'Etude et de Protection des Mammifères, Bourges, France.
Motta-Junior, J.C. AND V.A. TADDEI. 1992. Bats as prey of Stygian Owls in southeastern Brazil. Journal of Raptor Research 26:259-260.

Pierson, J.E. And P. Donahue. 1983. Peregrine Falcon feeding on bats in Suriname, South America. American Birds 37:257-259.

Pinchon, R. 1976. Les oiseaux, Second Ed. Fort-de-France, Martinique.

Rodet, J. 1987. La spéléologie des îles calcaires de la Grande-Terre et de Marie-Galante. Pages 227-236 in Proceedings of the $8^{\text {th }}$ Swiss Speleological Society Congress, Swiss Speleological Society, Turgi, Switzerland.

Rodriguez-Duran, A. AND A.R. LewIS. 1985. Seasonal predation by Merlins on sooty mustached bats in western Puerto Rico. Biotropica 17:71-74.

- AND T.H. KunZ. 2001. Biogeography of West Indian bats: an ecological perspective. Pages 355-368 in C.A. Woods and F.E. Sergile [EDs.], Biogeography of the West Indies: patterns and perspectives. CRC Press, Boca Raton, FL U.S.A.

SEIJAs, A.E. 1996. Feeding of the Bat Falcon (Falco rufigularis). Journal of Raptor Research 30:33-35.

SICK, H. 1961. Peregrine Falcon hunting bats while wintering in Brazil. Auk 78:646-648.

Smallwood, J.A. And D.M. Bird. 2002. American Kestrel (Falco sparverius). In A. Poole [ED.], The birds of North America online, No. 179. Cornell Lab of Ornithology, Ithaca, NY U.S.A. http://bna.birds.cornell.edu/ bna/species/602 (last accessed 28 February 2013).

SOUbeyran, Y., S. CACERES, AND N. Chevassus (DIR). 2011. Les vertébrés terrestres introduits en outre-mer et leurs impacts. Guide illustré des principales espèces envahissantes. UICN French Committee, Office nationale de la Chasse et de la Faune Sauvage, Aurillac, France.

Sprung, A., JR. 1950. Hawk predation at the bat caves of Texas. Texas Journal of Science 2:462-470.

StAGER, K.E. 1941. A group of bat-eating duck-hawk. Condor 43:137-139.

STONER, D. 1939. Eastern sparrow hawk feeding on big brown bat. Auk 22:153.

Received 15 April 2013; accepted 29 October 2013 